\title{
FAKTOR KECEMASAN TENAGA KESEHATAN DALAM MEMBERIKAN PERAWATAN PADA PASIEN COVID-I9: A LITERATUR REVIEW
}

\section{Factors Anxiety In Health Workers Providing To Patient Care Covid- 19 : A Literature Review}

\author{
Hermanto ${ }^{1 *}$ \\ Putria Carolina ${ }^{2}$ \\ Siti Santy Sianipar ${ }^{3}$ \\ *I Dosen Profesi Ners, STIKES \\ Eka Harap, Palangka Raya, \\ Kalimantan Tengah, Indonesia \\ 2 Dosen Diploma Keperawatan, \\ STIKES Eka Harap, Palangka \\ Raya, Kalimantan Tengah, \\ Indonesia \\ *email: \\ hermantosuhin87@gmail.com
}

\begin{abstract}
Abstrak
Latar Belakang: Covid-19 sebagai pandemic global membuat sistem pelayanan kesehatan global menjadi kewalahan dan tenaga medis mengalami beban kerja yang besar akibat dari shif dinas yang panjang sehingga berdampak pada gangguan psikologis salah satunya adalah kecemasan, kecemasan yang dilami bervariasi mulai ringan, sedang, hingga berat.

Tujuan: megetahui dan menampilkan apa saja penyebab kecemasan yang muncul pada tenaga kesehatan selama menangani pasien covid-19 melalui penelusuran artikel literatur

Metode: Metoode Penelitian ini adalah literatur review, dengan penelusuran artikel dimulai dari tahun 2019-2020, menggunakan database Proquest,PubMed, Sciencedirect.com, google scoolar, dan Crossreff dengan kata kunci Health Workers Anxiety OR Nurse Anxiety OR Covid-19 patien. identifikasi artikel ditemukan senbanyak 620 artikel dan masuk seleksi kriteria inklusi sebanyak 10I artikel.

Hasil: Didapatkan I0I artikel masuk dalam seleksi kriteria sesuai inklusi, didapatkan sebanyak II artikel yang memenuhi kriteria inklusi. II artikel dilakukan ekstraksi dan didapatkan beberapa factor meliputi jenis kelamin, usia, pendidikan, status perkawina, ketersedian APD, takut tertular, adanya penyakit penyerta, memiliki anggota keluarga lansia, kondisi dan lingkungan kerja, kontak langsung, tife RS, profesi, riwayat kecemasan, kejujuran pasien.

Kesimpulan: factor penyebab kecemasan pada tenaga kesehatan ketika merawat pasien covid-19 terjadi dari factor internal dan eksternal individu. Terjadi dari factor internal individu meliputi jenis kelamin, usia, pendidikan, status perkawinan, ketakutan untuk tertular, adanya penyakit penyerta, memiliki riwayat kecemasan. factor eksternal meliputi ketersedian APD, memiliki anggota keluarga lansia, kondisi dan lingkungan kerja, kontak langsung, tife RS, profesi, kejujuran pasien.
\end{abstract} Abstract
Background: Covid-19 as a global pandemic has overwhelmed the global health care
system and medical personnel experience a large workload due to long service shifts,
which have an impact on psychological disorders, one of which is anxiety, the anxiety
experienced varies from mild, moderate, to severe. weight.
Purpose: to find out and display the causes of anxiety that arise in health workers while
dealing with COVID- 9 patients through searching literature articles
Methods: This research method is a literature review, with article searches starting from
$2019-2020$, using the proquest, pubMed, sciencedirect.com, google scoolar, and crossreff
databases with the keywords health workers anxiety, OR Nurse anxiety, OR covid-I9
patients. The identification of articles found as many as 620 articles and included in the
selection criteria for inclusion of I0I articles.
Results: There were 10 I articles that were included in the inclusion criteria selection, II
articles were found that met the inclusion criteria. II articles were extracted and found
several factors including gender, age, education, marital status, availability of APD, fear of
infection, presence of comorbidities, having elderly family members, working conditions
and environment, direct contact, type of hospital, profession, history of anxiety, patient
honesty.
Conclusion: the factors that cause anxiety in health workers when treating COVID-I9
patients occur from individual internal and external factors. Occurs from individual
internal factors including gender, age, education, marital status, fear of being infected,
the presence of comorbidities, having a history of anxiety. External factors include the
availability of APD, having elderly family members, working conditions and environment,
direct contact, type of hospital, profession, patient honesty.

Kata Kunci:

Kecemasan,

Tenaga Kesehatan,

Perawatan Pasien,

Covid-19.

Keywords:

Anxiety,

Health workers,

Patient Care,

Covid-19. 


\section{PENDAHULUAN}

Corona virus disease-19 adalah penyakit menular yang disebabkan oleh tipe baru coronavirus dengan gejala umum demam, kelemahan, batuk, kejang dan diare dan menjadi salah satu penyakit yang ditakuti di seluruh dunia. WHO menetapkan kasus covid-19 menjadi kasus pandemic global (WHO, 2020). Covid-19 sebagai pandemic global membuat system pelayanan kesehatan global menjadi kewalahan dan tenaga medis mengalami beban kerja yang besar akibat dari shif dinas yang panjang (X. Zhang et al., 2020), sehingga berdampak pada gangguan psikologis tenaga kesehatan (Khanagar et al., 2020); Yin \& Zeng, 2020; Wang et al., 2020; Pothiawala, 2020; Li et al., 2020; Ma et al., 2020; Odriozola-González et al., 2020; Preti et al., 2020; Xu et al., 2020; Y.-P. Zhang et al., 2020). Gangguan psikologis yang terjadi salah satunya adalah kecemasan yang bervariasi mulai ringan, sedang, hingga berat dan ringan (Liu et al., 2020; Cui et al., 2020; HosseinzadehShanjani et al., 2020; Rosyanti \& Hadi, 2020; Pan et al., 2020). Kecemasan merupakan perasaan yang kuat terhadap ketakutan atau kengerian akan suatu penyebab yang tidak diketahui (Black, M. Joyce., et.al. Alih Bahasa: Nampira R.A, 2014). Tenaga kesehatan sebagai garda depan dalam memutus mata rantai penularan mengalami beban kerja yang besar. Akibat beban kerja meningkat akan menimbulkan kelelahan jangka panjang, ancaman infeksi, dan frustrasi akibat kematian pasien (X. Zhang et al., 2020). Kecemasan yang terjadi menimbulkan manifestasi seperti penurunan nafsu makan atau gangguan pencernaan (59\%), kelelahan (55\%), sulit tidur (45\%), gugup (28\%), sering menangis (26\%), dan bahkan pikiran untuk bunuh diri (2\%) (Liu et al., 2020);Y.-P. Zhang et al., 2020;Sunjaya, 2020). Dari beberapa artikel penelitian yang sudah dilakukan tujuan penelitian hanya ingin mengetahui gangguan psikologis yang terjadi pada tenaga kesehatan di RS sebagai dampak merawat dan menangani pasien covid-19 karena itu, pada penelitian ini peneliti ingin megetahui dan menampilkan apa saja penyebab kecemasan yang muncul pada tenaga kesehatan selama menangani pasien covid-19 dengan menggunakan penelusuran artikel literatur.

Menurut Word Health Organisasion sebanyak 17.106.007 juta orang terinfeksi covid-19, sebanyak 668.910 ribu orang meninggal dunia, dan sebanyak 292.527 orang terinfeksi dalam waktu 24 jam (WHO, 2020). Indonesia salah satu negara yang terinfeksi dan menjadi urutan ke-24 negara di dunia dengan jumlah terkonfirmasi covid-19 positif terbanyak di dunia dengan jumlah 135.000, dan sebanyak 6.02I kasus meninggal dunia (Satgas Covid-19, 2020). Kalimantan Tengah sebanyak 2.131 orang terinfeksi, sebanyak I.558 orang sembuh dan sebanyak 99 orang meninggal dunia (Satgas Covid-19 Kalteng, 2020). Angka kejadian kecemasan pada tenaga medis yang merawat pasien covid-19 sebesar 12,5\% dari jumlah sampel 512 staf (Liu et al., 2020) dan sebesar I.837 (91,2\%) dari jumlah sampel 2110 (Hu et al., 2020).

Penyakit Coronavirus (COVID-19 adalah penyakit menular yang disebabkan oleh virus corona yang baru ditemukan di wuhan cina. Covid-19 memiliki manifestasi seperti demam, batuk, sesak napas, nyeri otot, kebingungan, sakit kepala, sakit tenggorokan, rinorea, nyeri dada, diare, dan mual dan muntah (Zhu et al., 2020).COVID-19 mengakibatkan penyakit pernapasan yang parah dan bahkan fatal termasuk sindrom gangguan pernapasan akut (Chen et al., 2020). Apabila terinfeksi virus COVID-19 akan mengalami penyakit pernapasan ringan hingga sedang dan sembuh tanpa memerlukan perawatan khusus (WHO, 2020). Terdapat beberapa golongan orang yang rentan terinfeksi covid- 19 yaitu orang lanjut usia, dan mereka yang memiliki masalah medis seperti penyakit kardiovaskular, diabetes, penyakit pernapasan kronis, dan kanker. Virus COVID-19 menyebar terutama melalui tetesan air liur atau keluarnya cairan dari hidung saat orang yang terinfeksi batuk atau bersin.

Untuk mencegah infeksi dan memperlambat penularan COVID-19, lakukan beberapa hal seperti cuci tangan 
secara teratur dengan sabun dan air, atau bersihkan dengan antiseptik berbasis alkohol.jaga jarak setidaknya I meter.Hindari menyentuh wajah.Tutupi mulut dan hidung saat batuk atau bersin. Tinggallah di rumah jika merasa tidak enak badan.Menahan diri dari merokok dan aktivitas lain yang melemahkan paru-paru (WHO, 2020; Satgas Covid-19, 2020).

\section{METODOLOGI}

Metode Penelitian yang digunakan dalam penelitian ini adalah literatur review, dengan Penelusuran artikel dimulai dari tahun 2019. literatur review ini dilakukan dengan mencari artikel publikasi di jurnal Proquest,PubMed, Sciencedirect.com, google scoolar, dan Crossreff menggunakan kata kunci Health Workers Anxiety,OR Nurse Anxiety, OR Covid-19 patien. dengan jumlah artikel pada semua database kemudian dibuat pemilihan berdasarkan kriteria inklusi sehingga artikel yang relevan diperoleh, maka data akan diekstraksi dari artikel dan kemudian dikelompokkan untuk disimpulkan. Kriteria peninjaunan literatur dapat dilihat pada tabel I.
Tabel I. Daftar Kriteria tinjauan literatur

\begin{tabular}{|c|c|}
\hline Inklusi & Eksklusi \\
\hline $\begin{array}{lrr}\text { I. Berfokus pada } & \text { Tenaga } \\
\text { Medis seperti } & \text { dokter, } \\
\text { perawat, bidan } & \text { yang } \\
\text { mengalami } & \text { permasalahan } \\
\text { psikologis } & \text { yaitu } \\
\text { kecemasan } & \end{array}$ & $\begin{array}{l}\text { Artikel yang berfokus } \\
\text { pada komunitas, pasien } \\
\text { serta tidak mengulas } \\
\text { psikologis kecemasan }\end{array}$ \\
\hline 2. Artikel tanpa intervensi & $\begin{array}{l}\text { Melakukan } \\
\text { Intervensi }\end{array}$ \\
\hline $\begin{array}{l}\text { 3. Studi yang menjelaskan } \\
\text { hasil penyebab /factor } \\
\text { kecemasan }\end{array}$ & $\begin{array}{l}\text { Tidak membahas } \\
\text { penyebab/factor } \\
\text { kecemasan, menjelaskan } \\
\text { prevalensi. }\end{array}$ \\
\hline $\begin{array}{l}\text { 4. Penelitian Qualitatif, cross } \\
\text { sectional study, cohor study }\end{array}$ & $\begin{array}{l}\text { Quasy Eksperimental, } \\
\text { Eksperimen. } \\
\text { Sistematik review }\end{array}$ \\
\hline $\begin{array}{l}\text { 5. Tahun publikasi } \\
2020\end{array}$ & Sebelum tahun 2019 \\
\hline
\end{tabular}

Setelah proses pemilihan artikel dengan kriteria yang sesuai sehingga hasil artikel kriteria inklusi berjumlah I0I artikel, maka dilakukan penilaian kritis,secara keseluruhan hasil artikel yang relevan dan dapat dilakukan tinjauan pustaka sebanyak II artikel. Proses pemilihan artikel dapat dilihat di gambar I.

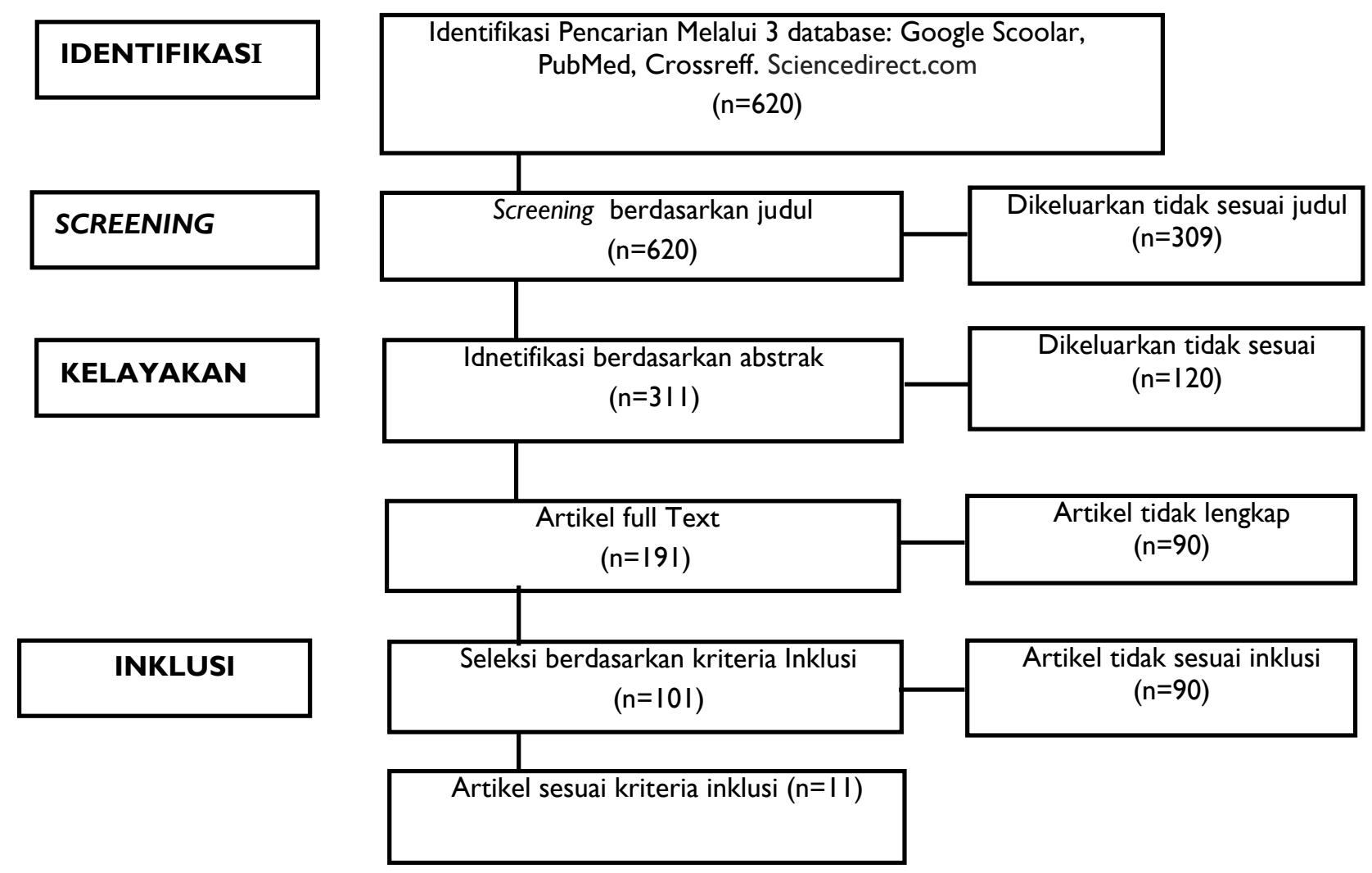




\section{HASIL DAN PEMBAHASAN}

\section{HASIL}

Artikel penelitian yang sesui dengan kriteria inklusi dilakukan penilaian kritis dan ekstraksi data kemudian data dikelompokan untuk didiskusikan dan disimpulkan sehingga berhasil didapatkan beberapa factor seperti (1) Jenis kelamin, (2) Usia, (3) pendidikan, (4) status perkawina, (5) ketersedian APD, (6) takut tertular, (7) adanya penyakit penyerta, (8) memiliki anggota keluarga lansia, (9) kondisi dan lingkungan kerja, (10) kontak langsung, (II) tife RS, (12) profesi, (13) riwayat kecemasan , (14) kejujuran pasien.

\section{Jenis kelamin,}

Dari hasil analisis artikel, jumlah responden berdasarkan jenis kelamin perempuan adalah yang paling banyak (Hu et al., 2020; Saleem, Majeed, Rafique, Siqqiqui, Ghandhi, Tariq, et al., 2020; Tercan et al., 2020b; Zhu et al., 2020). Tingkat kecemasan antara laki-laki dan perempuan terhadap covid-19 memiliki kecemasan sangat tinggi yaitu sebanyak 54,8\% (Soares, 2020). Dalam penelitian (Zhu et al., 2020) menemukan bahwa jenis kelamin laki-laki $(T=$ 2.970, $p=0.004,95 \% \mathrm{Cl}: 2.667 \sim$ 13.52 I) merupakan faktor pelindung terjadinya depresi pada dokter. Namun, pandangan bahwa perbedaan tingkat depresi secara universal lebih tinggi pada wanita daripada pria akan, hal ini perlu dilihat dari faktor penentu biologis, perubahan peran jenis kelamin, dan faktor sosial mungkin juga berkontribusi (Arenliu et al., 2016) Penelitian ini membuktikan bahwa jenis kelamin lakilaki atau perempuan tidak selalu menjadi prediktor signifikan dari reaktivitas emosional, seperti kecemasan dan ketakutan khusus pada masalah covid19. Kecemasan akan muncul ketika ada tekanan dari luar yang dapat menghambat aktivitas seseorang, baik pria maupun wanita.

\section{Usia}

Menurut penelitian (Liu et al., 2020); HosseinzadehShanjani et al., 2020; Chew et al., 2020) faktor penyebab kecemasan pada tenaga kesehatan saat perawatan pasien covid-19 salah satu yaitu usia, Kecemasan bisa dialami oleh siapa saja tidak terkecuali tenaga kesehatan yang berusia muda atau yang berusia tua dengan jenis kelamin laki-laki maupun perempuan (Soares, 2020);(Inter-Agency Standing Committee, 2020). Responden penelitian mengalami kecemasan pada usia berkisar 18-59 tahun hal ini menjelaskan bahwa kecemasan yang dialami tenaga kesehatan tidak memandang usia baik itu usia muda maupun usia tua di tengah masa pandemi Covid-19 (Fadli et al., 2020). Hal ini terjadi karena tenaga kesehatan merasa tertekan dan khawatir dalam menjalankan tugas serta adanya peningkatan jam kerja yang overload akan mempengaruhi kondisi tenaga kesehatan (Xu et al., 2020; Y.-P. Zhang et al., 2020)

\section{Pendidikan}

Tingkat pedidikan responden di dominasi Pendidikan sarjana, tingkat pendidikan yang tinggi akan berbanding luruh dengan tingkat pengetahuan yang baik tentang cara mencegah, merawat, dan mengobati masalah Covid-19 (Notoamojho,2012). tenaga kesehatan memiliki pengetahuan yang baik $(80,9 \%)$ terhadap pencegahan penularan virus. Tetapi masih banyak yang mengalami kecemasan ringan (Fadli et al., 2020). Hal ini bisa saja dipengaruhi karena tuntutan pekerjaan yang lebih tinggi, termasuk waktu kerja yang lama jumlah pasien yang meningkat (InterAgency Standing Committee, 2020).

\section{Status Perkawinan,}

Responden penelitian dalam artikel menjelaskan bahwa status perkawinan menikah lebih banyak pada responden. Menurut penelitian (Liu et al., 2020); Hosseinzadeh-Shanjani et al., 2020; Chew et al., 2020) salah satu faktor penyebab kecemasan pada tenaga kesehatan saat perawatan pasien covid-19 yaitu status perkawinan. factor status perkawinan menjadi hal yang penting yang dapat mengakibatkan kecemasan terutama dalam kondisi pandemic covid19 ini disebabkan karena kekhawatiran bahwa mereka 
akan menularkan virus Covid-19 kepada anggota keluarga (Shanafelt et al., 2020).

\section{Ketersediaan Alat Pelindung Diri.}

Alat Pelindung Diri (APD) merupakan Fasilitas alat pelindung diri yang wajib dikenakan oleh tenaga kesehatan selama melakukan perawatan pasien covid19. Alat pelindung diri mencakup sarung tangan, masker medis, kacamata atau pelindung wajah, dan baju pelindung, serta prosedur khusus, respirator (misalnya N95 atau standar FFP2 atau setara) dan celemek (WHO, 2020). Menurut (Lockhart et al., 2020) Terdapat 3 fungsi alat pelindung diri yakni untuk tetesan dan tindakan pencegahan kontak, untuk tindakan pencegahan melalui udara, tetesan, dan kontak umum, serta untuk mereka yang melakukan atau membantu dengan prosedur medis penghasil aerosol berisiko tinggi. Adanya kekurangan ketersedian alat pelindung diri yang kurang memadai bagi tenaga perawat yang bekerja di lingkungan kesehatan fisik akut akan memicu ketakutan dan kecemasan (Fadli et al., 2020). Hal ini penting menjadi perhatian karena berada di garda terdepan penanganan kasus, oleh karena itu mereka harus dibekali alat pelindung diri lengkap sesuai protokol dari WHO sehingga kecemasan yang dialami berkurang (J \& J, 2020).

\section{Takut Tertular Covid-I9.}

Factor kecemasan tenaga kesehatan adalah ketakutan tertular covid- 19 dari pasien yang dirawat (Zerbini et al., 2020). Ketakutan tertular merupakan bentuk kekhwahatiran tenaga kesehatan akibat kekurangan atau ketersediaan alat pelindung diri (Fadli et al., 2020). Menurut hasil penelitian (Bostan et al., 2020) dari 35 petugas kesehatan yang berpartisipasi dalam penelitian untuk menjalani pemeriksaan diagnostic covid-19 didapatkan hasil sebanyak 15 (43\%) orang positif. Hal ini sangat penting karena mengungkap risiko penularan COVID-19 ke petugas kesehatan. Lebih lanjut, jumlah perawat di Indonesia terkonfirmasi positif covid-19 per januari 2021 sebanyak 4977 orang tenaga perawat (PPNI PUSAT, 2020). Dan menurut kementerian kesehatan RI, per september 2020, sebanyak I0I petugas kesehatan terdiagnosis dan meninggal dunia karena COVID-19 (Kemenkes RI, 2020).

\section{Memiliki Penyakit Penyerta}

Penyakit penyerta atau komorbit merupakan masalah yang harus diperhatikan bagi tenaga kesehatan yang ditugaskan untuk menangani pasien covid-19. Menurut (Chew et al., 2020) salah satu factor kecemasan tenaga kesehatan yaitu adanya penyakit penyerta seperti hipertensi, hiperlipidemia, diabetes melitus, asma, eksim, migrain, merokok, penyakit jantung iskemik, stroke. Kondisi adanya penyakit penyerta kardiovaskular, diabetes, penyakit pernapasan kronis, dan kanker merupakan golongan orang yang rentan terinfeksi covid-I9 (WHO, 2020). Menurut hasil penelitian (Zhou et al., 2020) menjelaskan bahwa dari 19I pasien (I35 dari Rumah Sakit Jinyintan dan 56 dari Rumah Sakit Paru Wuhan) dalam penelitian ini pasien sebanyak 9 I (48\%) pasien memiliki komorbiditas seperti hipertensi, diabetes dan penyakit jantung coroner dan sebanyak 54 meninggal di rumah sakit.

\section{Memiliki Anggota Keluarga Lanjut Usia.}

Lanjut usia (lansia) memiliki resiko cukup tinggi terinfeksi covid-19, hal ini disebabkan adanya penurunan fungsi organ tubuh dan imunitas sebagai pertahanan tubuh (Winkelman, 2016). Menurut (WHO, 2020:Siagian, 2020) menjelaskan bahwa terdapat beberapa golongan orang yang rentan terinfeksi covid-19 yaitu orang lanjut usia. Menurut (Zhou et al., 2020) menjelaskan bahwa peningkatan kemungkinan kematian di rumah sakit terkait dengan usia yang lebih tua.

\section{Kondisi dan Lingkungan Kerja.}

Kondisi kerja yang berbeda bisa memicu kecemasan. Kondisi kerja yang berubah menjadi penting dan segera diatasi oleh tenag kesehatan untuk mengurangi 
tingkat kecemasan. Menurut hasil penelitian (Bostan et al., 2020) menjelaskan bahwa kondisi kerja tenaga kesehatan selama pandemic covid-19 memiliki tingkat kecemasan cukup tinggi. Semenjak covid-19 ditetapkan oleh WHO sebagai pandemic global membuat kondisi kerja dan system pelayanan kesehatan menjadi berubah dan tenaga medis mengalami beban kerja yang besar akibat dari shif dinas yang panjang (X. Zhang et al., 2020). Perubahan lingkungan kerja dalam hal ini adalah perubahan jumlah ruang perawatan di rumah sakit yang meningkat untuk pasien covid-19 sehingga terjadi peningkatan jumlah pasien yang dirawat dan berdampak pada peningkatan beban kerja perawat (Hu et al., 2020)

\section{I0. Melakukan Kontak Langsung.}

Pada dasarnya tenaga kesehatan memiliki resiko besar tertular penyakit dari pasien yang dirawat. Berdasarkan hasil penelitian (Bostan et al., 2020) sebanyak 3I,7\% petugas kesehatan pernah kontak dengan kasus COVID-19, dan sebanyak 27,3\% peserta memberikan layanan kepada pasien yang terdiagnosis COVID-19. Jumlah perawat di Indonesia terkonfirmasi positif covid-19 per januari 2021 sebanyak 4977 orang tenaga perawat garda terdepan dan kontak langsung dengan pasien (Satgas Penanganan Covid-19 DPP PPNI). Dan menurut kementerian kesehatan RI, per september 2020, sebanyak I0I petugas kesehatan terdiagnosis dan meninggal dunia karena COVID-19 (Kemenkes,2020). Tenaga kesehatan selama memberikan perawatan diharapkan selalu penerapkan tindakan pengendalian infeksi yang ketat, termasuk tindakan individu seperti mencuci tangan, menggunakan masker N95, celemek kerja, dan sarung tangan sebelum dan sesudah kontak dengan pasien (WHO, 2020).

\section{I. Tife Rumah Sakit}

Kekwahtiran tenaga kesehatan yang kerja di RS akan berbeda beda. Kecemasan tenaga kesehatan di RS pusat rujukan dan RS daerah pasti berbeda. Rumah sakit yang ditunjuk menerima hampir semua pasien COVID-I 9 yang dikonfirmasi, sedangkan rumah sakit distrik utama menerima sebagian besar pasien dengan penyakit tidak terinfeksi, dan rumah sakit daerah jauh dari pusat epidemi. Menurut hasil penelitian (Xiaoming et al., 2020) tenaga kesehatan di rumah sakit daerah memperlihatkan depresi, kecemasan tingkat tinggi, kecemasan, dan gejala somatik, selain itu, mereka memiliki skor stres tertinggi dan skor dukungan terendah. Hal ini beralasan karena pekerja rumah sakit daerah bekerja dengan peralatan khusus dan APD yang tidak mencukupi, pengalaman dan pelatihan yang kurang untuk mengatasi penularan, dan tanpa mengetahui apakah pasien menular, yang semuanya meningkatkan gejala dan tekanan psikologis mereka (Tsamakis et al., 2020). Hal ini bisa mengabitkan kayakinan tenaga keshatan terhadap rumah sakit tersebut menjadi kurang. Organisasi kesehatan dunia WHO menekanakan bahwa tenaga kesehatan yang melakukan pemeriksaan terhadap pasien covid-19 diharuskan mengunakan alat pelindung diri yang lengkap mencakup sarung tangan, masker medis, kacamata atau pelindung wajah, dan baju pelindung, serta prosedur khusus, respiratordan celemek (WHO, 2020)

\section{Profesi}

Dalam memberikan pelayanan kepada pasien dilakukan oleh multidisipliner ilmu seperti dokter, perawat, gizi, apoteker, labortorium. Profesi yang sering kontak secara langsung dengan pasien adalah dokter dan perawat tentu memiliki resiko yang paling tinggi sehingga resiko menimbulkan kecemasan (Bostan et al., 2020; Chew et al., 2020; Hu et al., 2020; Liu et al., 2020; Zhu et al., 2020). Berdasarkan hasil penelitian (Bostan et al., 2020) sebanyak 3।,7\% petugas kesehatan seperti dokter dan perawat pernah kontak dengan kasus COVID-19, dan sebanyak $27,3 \%$ peserta memberikan layanan kepada pasien yang terdiagnosis COVID-19. Profesi kesehatan yang memiliki tingkat kecemasan yang 
rendah terhadap covid-19 adalah apoteker dengan interaksi dengan pasien sangat terbatas (Saleem, Majeed, Rafique, Siqqiqui, Ghandhi, Tariq, et al., 2020).

\section{I3. Riwayat kecemasan.}

Adanya riwayat kecemasan atau depresi merupakan faktor risiko munculnya gejala kecemasan pada dokter, dan faktor risiko umum gejala kecemasan dan depresi pada perawat (Zhou et al., 2020). Penyakit mental sebelumnya secara signifikan terkait dengan kecemasan, depresi, atau morbiditas psikiatri umum dalam sampel narapidana di penjara Nigeria (Osasona SO et al.20I5). Untuk mengatasi dan meminimalkan kecemasan yang muncul akibat adanya riwayat kecemasan haru diimbangi dengan koping yang positif, adanya koping positif membantu dalam melawan emosi negative (Zhou et al., 2020). Pada tekanan psikologis stress yang dirasakan memiliki beberapa efek yang positif dan gaya koping menjadi mediator untuk mengatasi masalah (Y. Wang \& Wang, 2019)

\section{Kejujuran Pasien}

Kejujuran merupakan hal yang penting harus dimiliki antara tenaga kesehatan dengan pasien, keterbukaan informasi oleh pasien tentang penyakit yang dialami akan menciptakan perawatan yang maksimal sebaliknya, apabila pasien tidak jujur tentang informasi yang disampaikan akan menghambat proses penyembuhan dan berakibat kepada tenaga kesehatan akan tertular penyakit pasien. Banyak pasien merahasiakan riwayat kunjungan ke daerah wabah atau daerah yang sudah banyak menderita kasus covid-19 kepada petugas kesehatan (Fadli et al., 2020). 
Tabel 2. Hasil Tinjauan Artikel

\begin{tabular}{|c|c|c|c|c|}
\hline No & Peneliti dan Tahun & Design Penelitian & Responden Penelitian & Hasil Penelitian \\
\hline $\mathrm{I}$ & (Liu et al., 2020) & $\begin{array}{l}\text { Descriptive QuantitativCross- } \\
\text { Sectional Study }\end{array}$ & $\begin{array}{l}\text { Sebanyak } 512 \text { responden } \\
\text { meliputi perawat, dokter } \\
\text { dan bagian administratif }\end{array}$ & $\begin{array}{l}\text { Faktor Kecemasan: } \\
\text { I) Jenis kelamin, } \\
\text { 2) Usia, } \\
\text { 3) Pendidikan } \\
\text { 4) Status perkawinan } \\
\text { 5) Pernah melakukan kontak langsung }\end{array}$ \\
\hline 2 & (Zhu et al., 2020) & A cross-sectional survey & $\begin{array}{l}\text { Sebanyak } 165 \text { responden } \\
\text { dokter dan perawat }\end{array}$ & $\begin{array}{l}\text { Faktor Kecemasan: } \\
\text { I) Jenis Kelamin } \\
\text { 2) Riwayat kecemasan }\end{array}$ \\
\hline 3 & (Hu et al., 2020) & Cross-Sectional Study & $\begin{array}{l}\text { Sebanyak } 2000 \\
\text { responden perawat }\end{array}$ & $\begin{array}{l}\text { Faktor Kecemasan: } \\
\text { I) Profesi } \\
\text { 2) Perubahan Lingkungan kerja } \\
\text { 3) Keyakinan dalam merawat pasien COVID-I9 } \\
\text { 4) Keyakinan pada perlindungan diri, } \\
\text { 5) Keyakinan pada rumah sakit untuk mengatasi } \\
\text { wabah COVID-19. } \\
\text { 6emauan untuk berpartisipasi dalam pekerjaan } \\
\text { garis depan. }\end{array}$ \\
\hline 4 & $\begin{array}{l}\text { (Saleem, } \quad \text { Majeed, } \\
\text { Rafique, Siqqiqui, } \\
\text { Ghandhi, \& Tariq, } \\
\text { 2020) }\end{array}$ & $\begin{array}{l}\text { Cross-Sectional observational } \\
\text { Study }\end{array}$ & $\begin{array}{l}\text { Sebanyak } 404 \text { responden } \\
\text { dokter, perawat dan } \\
\text { farmasi. }\end{array}$ & $\begin{array}{l}\text { Faktor Kecemasan: } \\
\text { I) Usia } \\
\text { 2) Profesi }\end{array}$ \\
\hline 5 & (Tercan et al., 2020a) & Quantitatif, Studi Design & $\begin{array}{l}\text { Sebanyak } 331 \text { responden } \\
\text { perawat }\end{array}$ & $\begin{array}{l}\text { Faktor Kecemasan: } \\
\text { I) Memiliki anggota keluarga lanjut usia }\end{array}$ \\
\hline 6 & (Fadli et al., 2020) & $\begin{array}{l}\text { Cross-Sectional observational } \\
\text { Study }\end{array}$ & $\begin{array}{l}\text { Sebanyak I I5 responden } \\
\text { dokter dan perawat }\end{array}$ & $\begin{array}{l}\text { Faktor Kecemasan: } \\
\text { I) Usia } \\
\text { 2) Status keluarga } \\
\text { 3) Kejujuran pasien } \\
\text { 4) Ketersediaan alat pelindung diri. } \\
\text { 5) Pengetahuan. }\end{array}$ \\
\hline 7 & (Bostan et al., 2020) & A cross-sectional survey & $\begin{array}{l}\text { Sebanyak } 736 \text { responden } \\
\text { terdiri dari } 229 \text { dokter, } \\
309 \text { perawat, } 124 \text { tenaga } \\
\text { kesehatan lain } 74 \\
\text { administrasi }\end{array}$ & $\begin{array}{l}\text { Faktor Kecemasan: } \\
\text { I) Kondisi kerja } \\
\text { 2) Partisipasi dalam kondisi sosial }\end{array}$ \\
\hline 8 & $\begin{array}{l}\text { (Hosseinzadeh- } \\
\text { Shanjani et al., 2020) }\end{array}$ & $\begin{array}{l}\text { Descriptive study has a } \\
\text { cross-sectional design. }\end{array}$ & $\begin{array}{l}\text { Sebanyak } 535 \text { responden } \\
\text { terdiri dari perawat, } \\
\text { dokter, } \\
\text { administarasilaboratoriu } \\
\text { m, radiologi. }\end{array}$ & $\begin{array}{l}\text { Faktor Kecemasan: } \\
\text { I) Jenis kelamin } \\
\text { 2) Pendidikan } \\
\text { 3) Usia }\end{array}$ \\
\hline 9 & (Zerbini et al., 2020) & Cross-sectional survey & $\begin{array}{l}\text { Sebanyak I I0 responden } \\
\text { terdiri dari } 75 \text { orang } \\
\text { perawat dan } 35 \text { orang } \\
\text { dokter. }\end{array}$ & $\begin{array}{l}\text { Faktor Kecemasan: } \\
\text { I) Takut tertular COVID-19 }\end{array}$ \\
\hline 10 & (Chew et al., 2020) & & $\begin{array}{l}\text { Sebanyak } 906 \text { responden } \\
\text { terdiri dari dokter, } \\
\text { perawat,apoteker, } \\
\text { fisioterapis, } \\
\text { terapis okupasi), }\end{array}$ & $\begin{array}{l}\text { Faktor Kecemasan: } \\
\text { I) Usia, } \\
\text { 2) Jenis kelamin } \\
\text { 3) Penyakit penyerta }\end{array}$ \\
\hline II & $\begin{array}{l}\text { (Xiaoming et al., } \\
\text { 2020) }\end{array}$ & Cross-sectional study & $\begin{array}{l}8817 \text { responden pekerja } \\
\text { rumah sakit }\end{array}$ & $\begin{array}{l}\text { Faktor Kecemasan: } \\
\text { I) Tingkat rumah sakit } \\
\text { 2) Pendidikan }\end{array}$ \\
\hline
\end{tabular}




\section{KESIMPULAN}

Penyebab kecemasan pada tenaga kesehatan ketika merawat pasien covid-19 terjadi dari factor internal dan eksternal individu. Factor internal individu meliputi jenis kelamin, usia, pendidikan, status perkawinan, ketakutan untuk tertular, adanya penyakit penyerta, memiliki riwayat kecemasan. Factor eksternal meliputi ketersedian APD, memiliki anggota keluarga lansia, kondisi dan lingkungan kerja, kontak langsung, tife RS, profesi, kejujuran pasien.

\section{UCAPAN TERIMA KASIH}

Terima kasih kepada Ketua STIKES Eka Harap, Ketua LPPM STIKES Eka Harap, Ketua Program Studi Profesi Ners, Rekan-rekan dosen Keperawatan dan Profesi Ners dan semua pihak yang terlah terlibat dalam penelitian ini.

\section{REFERENSI}

I. WHO. (2020). Dasbor WHO Coronavirus Disease. https://covid 19. who.int/?gclid=CjOKCQjws536BR DTARIsANeUZ594yyL8OHnkKocY2 yFVIdD2wL iL2aWgX5syWZ0huuA0cd3kZj9UTUaAonwEAL w_wCB

2. Zhang, X., Jiang, Z., Yuan, X., Wang, Y., Huang, D., Hu, R., Zhou, J., \& Chen, F. (2020). Nurses reports of actual work hours and preferred work hours per shift among frontline nurses during coronavirus disease 2019 (COVID-19) epidemic: A cross-sectional survey. International Journal of Nursing Studies, 2019(xxxx). https://doi.org/10.1016/j.jinurstu.2020.103635

3. Khanagar, S. B., Al-Ehaideb, A., Vishwanathaiah, S., Maganur, P. C., Varadarajan, S., \& Patil, S. (2020). Depression, anxiety, and psychological distress among health-care providers during the outbreak of the life-threatening coronavirus disease (COVID-19). Journal of Contemporary Dental Practice, 2l(5), 47I-472. https://doi.org/10.5005/jp-journals-10024-2836

4. Yin, X., \& Zeng, L. (2020). A study on the psychological needs of nurses caring for patients with coronavirus disease 2019 from the perspective of the existence, relatedness, and growth theory. International Journal of Nursing
Sciences, 7(2), 157-160. https://doi.org/10.1016/j.ijnss.2020.04.002

5. Wang, S., Wen, X., Dong, Y., Liu, B., \& Cui, M. (2020). Psychological Influence of Coronovirus Disease 2019 (COVID-19) Pandemic on the General Public, Medical Workers, and Patients With Mental Disorders and its Countermeasures. Psychosomatics, I-9. https://doi.org/10.1016/j.psym.2020.05.005

6. Pothiawala, S. (2020). Cite this article as: Pothiawala S. Psychological Impact of the COVID19 on Health Care Workers in the Emergency Department. Adv J Emerg Med, 4(2s), 58. https://doi.org/10.221/4/ajem.v0i0.397

7. Li, G., Miao, J., Wang, H., Xu, S., Sun, W., Fan, Y., Zhang, C., Zhu, S., Zhu, Z., \& Wang, W. (2020). Psychological impact on women health workers involved in COVID-19 outbreak in Wuhan: A cross-sectional study. Journal of Neurology, Neurosurgery and Psychiatry, 9/(8), 895-897. https://doi.org/10.1 I36/jnnp-2020-323134

8. Ma, Y., Rosenheck, R., \& He, H. (2020). Psychological stress among health care professionals during the 2019 novel coronavirus disease Outbreak: Cases from online consulting customers. Intensive and Critical Care Nursing, xxxx, 102905. https://doi.org/10.1016/j.iccn.2020.102905

9. Odriozola-González, P., Planchuelo-Gómez, Á., Irurtia-Muñiz, M. J., \& de Luis-García, R. (2020). Psychological symptoms of the outbreak of the COVID-19 crisis and confinement in the population of Spain. https://doi.org//0.31234/osf.io/mq4fg

10. Preti, E., Di Mattei, V., Perego, G., Ferrari, F., Mazzetti, M., Taranto, P., Di Pierro, R., Madeddu, F., \& Calati, R. (2020). The Psychological Impact of Epidemic and Pandemic Outbreaks on Healthcare Workers: Rapid Review of the Evidence. Current Psychiatry Reports, 22(8). https://doi.org/|0.1007/s I 1920-020-01 I66-z

II. Xu, J., Xu, Q. hui, Wang, C. ming, \& Wang, J. (2020). Psychological status of surgical staff during the COVID-19 outbreak. Psychiatry Research, 288(March), II 2955 https://doi.org/10.1016/j.psychres.2020.112955

12. Zhang, Y.-P., Yuan, H.-T., Song, Y.-Q., Jia, J., Mi, W., Wang, Y.-L., Wang, J., Li, D.-Y., \& Zhu, W. (2020). Nurses suffered with more psychological symptoms when fighting against novel coronavirus pneumonia (COVID-19): a longitudinal observational survey of medical staff. I-I5. https://doi.org/| 0.21203/rs.3.rs-35668/v| 
13. Liu, C. Y., Yang, Y. Z., Zhang, X. M., Xu, X., Dou, Q. L., Zhang, W. W., \& Cheng, A. S. K. (2020). The prevalence and influencing factors in anxiety in medical workers fighting COVID-19 in China: A cross-sectional survey. Epidemiology and Infection, | 48. https://doi.org/10.1017/S095026882000| I07

14. Hosseinzadeh-Shanjani, Z., Hajimiri, K., Rostami, B., Ramazani, S., \& Dadashi, M. (2020). Stress, anxiety, and depression levels among healthcare staff during the COVID-19 epidemic. Basic and Clinical Neuroscience, II(2), I63-170. https://doi.org/10.32598/bcn.I I.covid 19.65I.4

I5. Rosyanti, L., \& Hadi, I. (2020). Dampak Psikologis dalam Memberikan Perawatan dan Layanan Kesehatan Pasien COVID-19 pada Tenaga Profesional Kesehatan. Health Information: Jurnal Penelitian, 12(1), 107-130. https://doi.org/10.36990/hijp.vi.I9I

16. Pan, R., Zhang, L., \& Pan, J. (2020). The anxiety status of chinese medical workers during the epidemic of COVID-19: A meta-analysis. Psychiatry Investigation, $\quad$ I7(5), 475-480. https://doi.org//0.30773/pi.2020.0127

17. Black, M. Joyce., et.al. Alih Bahasa: Nampira R.A, et. a. (20|4). Keperawatan Medikal Bedah;Manajemen klinis untuk hasil yang diharapkan (8th ed.). Elsevier (Singapore) Pte. Ltd.

18. Satgas Covid-19. (2020). Informasi Perkembangan Covid-1 9 di Indonesia. https://covid I 9.go.id/

19. Satgas Covid-19 Kalteng. (2020). Perkembangan dan Peta Sebaran Kasus COVID-19 di Kalimantan Tengah. https://corona.kalteng.go.id/

20. Hu, D., Kong, Y., Li, W., Han, Q., Zhang, X., Zhu, L. X., Wan, S. W., Liu, Z., Shen, Q., Yang, J., He, H. G., \& Zhu, J. (2020). Frontline nurses' burnout, anxiety, depression, and fear statuses and their associated factors during the COVID-19 outbreak in Wuhan, China: A large-scale cross-sectional study. EClinicalMedicine, 24, 100424. https://doi.org/10.1016/j.eclinm.2020.100424

21. Zhou, F., Yu, T., Du, R., Fan, G., Liu, Y., Liu, Z., Xiang, J., Wang, Y., Song, B., Gu, X., Guan, L., Wei, Y., Li, H., Wu, X., Xu, J., Tu, S., Zhang, Y., Chen, H., \& Cao, B. (2020). Clinical course and risk factors for mortality of adult inpatients with COVID-19 in Wuhan, China: a retrospective cohort study. The Lancet, 395(10229), 1054-1062. https://doi.org//0.1016/S0140-6736(20)30566-3
22. Hu, D., Kong, Y., Li, W., Han, Q., Zhang, X., Zhu, L. X., Wan, S. W., Liu, Z., Shen, Q., Yang, J., He, H. G., \& Zhu, J. (2020). Frontline nurses' burnout, anxiety, depression, and fear statuses and their associated factors during the COVID-19 outbreak in Wuhan, China: A large-scale cross-sectional study. EClinicalMedicine, 24, 100424. https://doi.org//0.1016/j.eclinm.2020.100424

23. Saleem, Z., Majeed, M. M., Rafique, S., Siqqiqui, Z., Ghandhi, D., Tariq, H., \& Zegarra-Valdivia, J. A. (2020). COVID- 19 pandemic fear and anxiety among healthcare professionals in Pakistan. I-I7. https://doi.org//0.21203/rs.3.rs-37608/v1

24. Soares, A. P. (2020). PERBEDAAN TINGKAT KECEMASAAN ANTARA MAHASISWA LAKILAKI DAN PEREMPUAN TERDAMPAK PANDEMI COVID -19. Journal of Chemical Information and Modeling, 53(9), 1689-1699.

25. Zhu, J., Sun, L., Zhang, L., Wang, H., Fan, A., Yang, B., Li, W., \& Xiao, S. (2020). Prevalence and Influencing Factors of Anxiety and Depression Symptoms in the First-Line Medical Staff Fighting Against COVID-19 in Gansu. Frontiers in Psychiatry, I I (April), I-6. https://doi.org/10.3389/fpsyt.2020.00386

26. Arenliu, A., Kelmendi, K., \& Berxulli, D. (20/6). Gender differences in depression symptoms: Findings from a population survey in Kosovo - A country in transition. Psychological Thought, 9(2), 236-247. https://doi.org/10.5964/psyct.v9i2.198

27. Chew, N. W. S., Lee, G. K. H., Tan, B. Y. Q., Jing, M., Goh, Y., Ngiam, N. J. H., Yeo, L. L. L., Ahmad, A., Ahmed, F., Napolean, G., Sharma, A. K., Komalkumar, R. N., \& Meenakshi, P. V. (2020). A multinational, multicentre study on the psychological outcomes and associated physical symptoms amongst healthcare workers during COVID- 19 outbreak. January.

28. Inter-Agency Standing Committee. (2020). Catatan Tentang Aspek Kesehatan Jiwa dan Psikososial Wabah Covid-19 Versi I.0. Who, Feb, I-20.

29. Fadli, F., Safruddin, S., Ahmad, A. S., Sumbara, S., \& Baharuddin, R. (2020). Faktor yang Mempengaruhi Kecemasan pada Tenaga Kesehatan Dalam Upaya Pencegahan Covid-19. Jurnal Pendidikan Keperawatan Indonesia, 6(I), 57-65. https://doi.org/10.17509/jpki.v6il.24546 
30. Shanafelt, T., Ripp, J., \& Trockel, M. (2020). Understanding and Addressing Sources of Anxiety among Health Care Professionals during the COVID-19 Pandemic. JAMA - Journal of the American Medical Association, 323(21), 2133-2134. https://doi.org/10.100I/jama.2020.5893

3I. J, M., \& J, B. (2020). Covid-19: Supporting nurses' psychological and mental health. Journal of Clinical Nursing.

32. Kemenkes RI. (2020). KEMENTRIAN KESEHATAN REPUBLIK INDONESIA: Kesiapsiagaan Menghadapi Covid-19. https://www.kemkes.go.id/

33. Zerbini, G., Ebigbo, A., Reicherts, P., Kunz, M., \& Messman, H. (2020). Psychosocial burden of healthcare professionals in times of covid-19-a survey conducted at the university hospital augsburg. GMS German Medical Science, 18, I-9. https://doi.org//0.3205/000281

34. Bostan, S., Akbolat, M., Kaya, A., Ozata, M., \& Gunes, D. (2020). Assessments of anxiety levels and working conditions of health employees working in COViD-19 pandemic hospitals. Electronic Journal of General Medicine, I7(5). https://doi.org/10.29333/ejgm/8228

35. PPNI PUSAT, S. C.-19. (2020). Tim Penanganan Covid-1 9 Dewan Pengurus Pusat - Persatuan Perawat Nasional Indonesia. https://www.covid I9ppni.id/form-pantauanperawat/

36. Winkelman. (2016). Winkelman (2016) Clinical Companion for Medical-Surgical Nursing PatientCentered Collaborative Care, 8e.pdf.

37. Siagian, T. H. (2020). MENCARI KELOMPOK BERISIKO TINGGI TERINFEKSI VIRUS CORONA DENGAN DISCOURSE NETWORK ANALYSIS. Jurnal Kebijakan Kesehatan Indonesia, 09(02), 98-106.

38. Xiaoming, X., Ming, A., Su, H., Wo, W., Jianmei, C., Qi, Z., \& Hua, H. (2020). The psychological status of 8817 hospital workers during COVID-19 Epidemic: A cross-sectional study in Chongqing. January.

39. Tsamakis, K., Rizos, E., Manolis, A., Chaidou, S., Kympouropoulos, S., Spartalis, E., Spandidos, D., Tsiptsios, D., \& Triantafyllis, A. (2020). [Comment] COVID-19 pandemic and its impact on mental health of healthcare professionals. Experimental and Therapeutic Medicine, 345I-3453.

\section{https://doi.org// 0.3892/etm.2020.8646}

40. Tercan, M., Bozkurt, F. T., Patmano, G., Saraçoğlu, G., \& Gür, S. C. (2020a). Anxiety and Depression Differences Between the Nurses Working at a COVID-I 9 Pandemic Hospital. Medical Science and Discovery, 6-II. https://doi.org// 0.36472/msd.v7i6.389

4I. Tercan, M., Bozkurt, F. T., Patmano, G., Saraçoğlu, G., \& Gür, S. C. (2020b). Anxiety and Depression Differences Between the Nurses Working at a COVID-19 Pandemic Hospital. Medical Science and Discovery, 7(6), 526-531. https://doi.org// 0.36472/msd.v7i6.389 